\title{
GIDA ENDÜSTRİSİNDE EKSTRÜZYON TEKNOLOJİSİNİN KULLANIMI VE YAPILAN OPTİMIZZASYON ÇALIŞMALARI
}

\author{
Ayşe Merve Büyükyazi ${ }^{1 *}$, Şebnem Tavman ${ }^{2}$ \\ ${ }^{1 *}$ Ege Üniversitesi, Fen Bilimleri Enstitüsü, Gıda Mühendisliği Anabilim Dalı, İzmir, Türkiye \\ ${ }^{2}$ Ege Üniversitesi, Mühendislik Fakültesi, Gıda Mühendisliği Bölümü, İzmir, Türkiye
}

Geliş / Received: 04.03.2020; Kabul / Accepted: 14.07.2020; Online bask1 / Published online: 08.08.2020

Büyükyazı, A.M., Tavman, Ş. (2020). Gıda endüstrisinde ekstrüzyon teknolojisinin kullanımı ve yapılan optimizasyon çalışmaları. GIDA (2020) 45(4) 774-785 doi: 10.15237/gida.GD19140.

Büyükeyazl, A.M., Tavman, S. (2020). Application of extrusiontechnology and optimizationstudies in the foodindustry. GIDA (2020) 45 (4) 774-785 doi: 10.15237/gida.GD19140.

ÖZ

Gıda endüstrisinde ekstrüzyon pişirme; enerji tüketiminin az olmas1, üretimin verimli ve son ürünün ucuz olması, yeni teknolojilerden olması, yüksek sıcaklık-kısa süreli işleme yöntemi olmasından dolayı tercih edilen ve kullanımı gittikçe artan bir yöntemdir. Ekstrüzyon pişirme esnasında ekstrüdere giren hammaddenin özellikleri (nişasta tipi, protein, yağ, su içeriği, formülasyonvd.), proses değişkenleri (vida hızı, besleme hızı, kalıp şekli ve sıcaklığı gibi) ve ürün karakteristikleri (besinsel, fiziksel ve kimyasal özellikler gibi) arasında önemli bir ilişki bulunmaktadır. Değişkenleri doğru analiz edebilmek ve yapılacak deney sayısını en uygun şekilde azaltabilmek için optimizasyon çalışmalarının yapılması gerekmektedir. Mühendislik açısından optimizasyon, prosesleri etkileyen bağımsız değişkenler ve yanıt olarak adlandırılan bağımlı değişkenler arasındaki ilişkileri değerlendirerek optimum verilerin oluşmasını sağlamaktadır. Bu derlemenin amacı, ekstrüzyon tekniği ile üretilmiş ürünlerle ilgili yanıt-yüzey yöntemiyle yapılan optimizasyon çalısmalan bir arada değerlendirmektir.

Anahtar kelimeler: Gıda endüstrisi, ekstrüzyon, ekstrüde ürün, optimizasyon

\section{APPLICATION OF EXTRUSION TECHNOLOGY AND OPTIMIZATION STUDIES IN THE FOODINDUSTRY}

\begin{abstract}
Extrusion cooking is preferred due to its low energy consumption, efficient production and cheap end products, adaptability to new technologies, high temperature-short-term processing method and it is increasingly used in the food industry. There is an important relations between raw material entering the extruder (starch type, protein, oil, water content, formulation etc.), process variables (such as screw speed, feed rate, barrel shape and temperature) and product characteristics (such as nutritional, physical and chemical properties) during the extrusion cooking and many factors come into play to reach the desired product. Optimization studies are required to analyze these factors well and to decrease the number of experiments in the most logical way. In terms of engineering, optimization ensures optimum data by evaluating the relationships between independent variables that affect processes and dependent variables called responses. The purpose of this review is to evaluate the optimization studies carried out using the response-surface method for products produced by extrusion technique.
\end{abstract}

Keywords: Food industry, extrusion, extruded product, optimization

\footnotetext{
* Yazışmalardan sorumlu yazar/ Corresponding author

$\triangle$ :bykyz.merveayse@gmail.com

(ग):(+90)544 9646411
}

且:(+90)232311 4831

Ayşe Merve Büyükyazı; ORCID no: 0000-0003-4942-5897

Şebnem Tavman; ORCID no: 0000-0002-3069-1709 


\section{GİRIŞ̧}

Toplumun yaşam tarzındaki değişiklikler, beslenme alıskanlıklarının değişmesine ve dolayısıyla tüketime hazır, kolay taşınabilen, çabuk tüketilebilen gıdalara yönelimi artırmıstır. Günümüzde teknoloji ve buna bağlı olarak gida işleme tekniklerindeki gelişmeler değişik gıda ürünlerinin tüketicilere sunulmasina neden olmuştur (Maskan ve Altan, 2012). Bu tarz gıdalara yönelim ise beraberinde ekstrüzyon teknolojisinin g1da işleme endüstrisinde önemli bir paya sahip olmasını getirmiştir. Ekstrüde ürünlerle ilgili olarak yapılan çalışmalarda, ekstrüzyon sirasinda hammaddelerin kimyasal, mikrobiyolojik ve yapısal değişimlerden geçtiği (nişasta jelatinizasyonu, protein denatürasyonu, enzim inaktivasyonu, mikrobiyel sayımda düşüş vb.) ve son ürünün özelliklerini etkileyen besinsel içerik, organoleptik özellikler, kalite kriterleri gibi pek çok faktörün bulunduğu görülmüsstür (Sawant vd., 2015).Proses sirasında en etkili ve verimli üretimi gerçekleştirmek gida endüstrisinin önemli bir hedefidir (Yolmehve Jafari, 2017). Dolayisiyla istenilen en iyi özelliğe sahip ekstrüde ürünü üretebilmek, prosesi daha verimli hale getirebilmek ve kaliteyi iyileştirebilmek için ise optimizasyon çalışmalarına ihtiyaç duyulmaktadır.

Optimizasyon; bir proseste istenen ürüne ait özellikler yani yanıtlara ulaşılması amacı ile, bağımsız değisskenlerin kendi aralarındaki etkileşimlerinin ve hedefe (yanıta) olan etkilerinin bir arada değerlendirilmesi işlemidir (Koç ve Kaymak-Ertekin, 2010). Optimizasyonda kullanılan yöntemlerden yanıt yüzey metodu genel olarak; problemin tanımı, bağımsız değişkenler ve derecelerinin belirlenmesi, doğru tasarım seçimi ve sonucunda modelin oluşturulmasi, optimizasyonu ve değerlendirilmesi aşamalarından oluşmaktadır. Daha az sayıda deneme oluşturulması için tasarımlar arasında eleme yapılmalı ve bağımsız değişkenlerin optimum noktaya en yakın sonuç verdiği tasarım araştırılmalıdır (Aydar, 2018).

$\mathrm{Bu}$ derlemede,ekstrüzyon tekniği, ekstrüzyon tekniğinin gida işleme endüstrisinde kullanım alanları ve ekstrüzyon tekniği ile elde edilen ürünlerde yapılan optimizasyon çalışmaları ile bu çalışmaların sonuçlarından bahsedilecektir.

\section{EKSTRÜZYON TEKNİĞİ VE KULLANIM ALANLARI}

Ekstrüzyon, 20.yüzyllın en önemli yeniliklerinden biri olmakla beraber, genellikle polimer ve plastikler, gida ve yem, kağıt-değirmencilik endüstrileri gibi pek çok farklı işleme endüstrilerinde tercih edilmektedir. G1da endüstrisinde bir pişirme işlemi olarak ekstrüder kullanımının, ilk defa 1940'lı yıllarda aperatif gida üretmek için olduğu bilinmektedir. Ekstrüzyon teknolojisi çeşitli gida proseslerine uygulanabilen bir yöntem olup, endüstride olduğu gibi akademik çalışmalarda da yerini önemli derecede almıstır (Tiğa, 2018).

\section{Ekstrüzyon Teknolojisi}

Ekstrüzyon işlemi karıştırma, 1sıtma, kesme gibi birçok işlemin birleştirildiği, hamurun kalıptan itildiği bir proses olarak tanımlanmakta olup, sistem içindeki materyallerin akışı, bu materyallerin kendi aralarındaki termal enerji aktarımlanı ve prosesteki kütle aktarımlarından oluşan bir taşıma işlemidir (Ajita, 2018). Gıda uygulamalarında vidalı ekstrüzyon baskın olmakla beraber, ekstrüderler çift vidalı ve tek vidalı olarak ikiye ayrılmaktadır. Çift vidalı ekstrüderler daha karmaşıktır fakat tek vidalı ekstrüderlere göre daha kontrollü bir üretim yapılmasına olanak sağlarlar (Tiğa, 2018). Bir ekstrüder besleme haznesi, ön 1sıtıc1, 1sıtma bölgesi ve kalıp bölmelerinden oluşmaktadır. Ekstürderde dönen vida tarafindan kayma enerjisi oluşturulur, kovanın da 1situlması ile birlikte gida maddesi erime noktasına getirilir ve yüksek basınç altında kalıptan geçirilerek son halini almış olur. Sonuçta ekstrüzyon pişirme esnasında, gıda hammaddeleri nem, basınç, sıcaklık faktörlerinin etkisi ile birkaç dakika içerisinde pişirilir, bu durum ise moleküler dönüşüm ve kimyasal reaksiyonlarla sonuçlanır (Navale vd., 2015).

\section{Ekstrüzyon Tekniğinin Kullanım Alanları}

Diğer gida işleme teknolojilerine oranla ekstrüzyon teknolojisi çok yönlülüğü, yüksek verimliliği, düşük maliyeti, enerji verimliliği ve az miktarda atık su oluşumu gibi özellikleri sayesinde son yıllarda çok tercih edilen bir teknoloji haline 
gelmiştir. Ekstrüzyon pişirme teknolojisi sayesinde makarna, bebek mamaları, kahvaltılik tahıllar, atıştırmalık gıda ürünleri, şekerlemeler, tekstüre edilmiş proteinli gıda ürünleri, evcil hayvan mamaları gibi geniş çeşitlilik aralığında gıda ürünlerinin üretimi daha kolaylaşmıştır (Tiğa, 2018).Fakat ekstrüzyon pişirmede ürünlerin besin değerinde azalma görülmektedir ve bu nedenle gıda işleme esnasında lif ve biyoaktif bileşen açısından zenginleşmeye yardımcı olacak ürünler ilave edilmektedir. Ekstrüzyon yöntemi ile pişirilmiş ürünleri bu yönde zenginleştirmek için Ovando-Martinez vd. (2009) ham muz tozu, Silva vd. (2013) brokoli tozu, Rajesvari vd. (2013) soğan tozu, Lu vd. (2018) mantar tozunu çalışmalarına dahil etmişlerdir. Son zamanlarda çok dikkat çeken amarant ve kinoa da besinsel değerlerinden dolayı Cardenes-Hernandez vd. (2016) ile Bastos vd. (2016) tarafindan tercih edilmiştir. Glutensiz ürün üretiminde de bu teknoloji tercih edilmekte olup birçok baklagil unu, enginar, havuç, brokoli, ayçekirdeği, sarı biber, kırmızı biber gibi sebze tozları, soya ile zenginleştirilmiş pirinç unu, patates püresi/unu ile ilgili çalışmalar olmuştur (Maskan ve Altan, 2012). Giuberti vd. (2015) pirinç unu ve farklı oranlarda bezelye unları ile, Cappa vd. (2017) patates ve patates türevleri ile, Patino-Rodriguez vd. (2018) ise olgunlaşmamış muz, mısır ve nohut unları ile çalışmıs ve çölyak hastaları için ekstrüzyon teknolojisi kullanarak glütensiz ürün üretmeyi amaçlamışlardır.

Ayrıca kırmızı/beyaz et, süt ve süt ürünleri, meyve/sebze ve balık endüstrisinde işleme esnasında oluşan yan ürün ve attkların değerlendirilmesinde de ekstrüzyon teknolojisi ciddi derecede katkı sağlamaktadır (Waldron, 2007). Gıda yan ürün/attklarının ekstrüzyon tekniğinde değerlendirilme sebepleri olarak; gida endüstrisinin insan sağlığına zararlı etkileri olan fazla miktarda yan ürün/atık oluşturması (Helkar ve Sahoo, 2016), hizlı nüfus artşssonucunda atıkların oluşumunun da artması ve bu durumun çevreye zarar vermesi, açlı̆̆ın yüksek olduğu ülkelerde insanlara zenginleştirilmiş ürünler verebilme isteği (Torres-Leon vd., 2018) gösterilmektedir. Surasani (2016) balık endüstrisi, Sharma vd. (2016)pirinç endüstrisi yan ürünleri ile çalışmışlardır. Meyve sebze endüstrisinde elma, şeftali, portakal, domates, muz posası ve kabuğu, soğan kabuğu, kayıs1, üzüm, nar çekirdeği ve posalarının ekstrüdere girecek olan karışıma belli oranlarda ilaveleri ile çeşitli ürünler elde edilmektedir (Maskan ve Altan, 2012).

Ancak Ackar vd. (2018), yaptıkları çalışmada ekstrüzyon tekniği ile üretilen ve gida yan ürünleri ile zenginleştirilen ürünlerde zayıf genişleme (ürünün kesit alanı ile kalıp alanı arasındaki oran) etkisi görüldügünden bahsetmiş ve bu nedenle çalışmalarına bira posası, şeker pancarı pulpu ve elma posasını atı̧şırmalık ürün üretiminde kullanmışlar ve zayıf genişleme problemini çözmek amaçlı ise $\% 0.5$ ve $\% 1$ oranlarında pektin ilavesi yapmışlardır. Çalışmanın sonucunda ürünlerde kabul edilebilir seviyede genişleme sağlandığ1 görülmüştür. Ayrıca Rizvi ve Paraman(2015) yaptıkları patent çalışmasında ekstrüzyon tekniği ile peynir altı suyu proteini ve meyve posasını (elma ve üzüm) birlikte değerlendirerek sağlıklı atıştırmalık üretmek istemişlerdir. Ekstrüde ürünlerde antioksidan aktivite ve toplam fenolik madde miktarını koruyabilmek için sistemi süper kritik akışkanı ile desteklemişler ve sonuç olarak ürünlerde antioksidan aktivitesi ile toplam fenolik madde miktarının korunması sağlanmıştır. Yapılan bu çalışmalarda ise sonuç üzerinde etkili olan faktörleri en iyi şekilde yorumlayabilmek amacıyla optimizasyon çalışmaları bir araç olmuştur.

\section{EKSTRÜZYON TEKNOLOJİII İLE ÜRETİLEN ÜRÜNLERDE YAPILAN OPTIMMIZZASYON ÇALIŞMALARI}

Son yıllarda gida teknolojisinde, yanıt yüzey yöntemi çok ihtiyaç duyulan bir uygulama alanı olarak yerini almıştır. Yanıt yüzey yöntemi, bağımsız değişken olarak adlandırılan faktörlerin hem kendi aralarındaki etkileşimlerinin hem de birden çok yanıt üzerindeki etkilerinin değerlendirilmesine ve sonuçta optimum sonuç elde edilmesine olanak verir (Aydar, 2019).Ekstrüzyon işlemi ile üretilen gida ürünleri ile ilgili yapılan optimizasyon çalışmalarında yanıt yüzey metodu, CCRD (Merkezi Tümleşik Tasarım)metodu ve D-Optimal Karışım tasarımı en ideal araçlar olarak görülmektedir (Danbaba vd., 2016).Çizelge.1' de bazı ekstrüzyon araştırmalarında uygulanan optimizasyon çalışmaları tablo haline getirilmiştir. 
Çizelge 1. Bazı ekstrüzyon çalışmalarında yapılmış optimizasyon uygulamaları

\begin{tabular}{|c|c|c|c|}
\hline Çalışılan Ürün & $\begin{array}{l}\text { Bağımsız Değişkenler / } \\
\text { Yanitlar }\end{array}$ & $\begin{array}{l}\text { Optimizasyon tasarımı/ } \\
\text { Optimum sonuçlar }\end{array}$ & Kaynak \\
\hline $\begin{array}{l}\text { Arpa unu-üzüm } \\
\text { posas1 ekstrüde } \\
\text { ürünü }\end{array}$ & $\begin{array}{l}\text { Kalıp sıcaklığı }\left(140-160^{\circ} \mathrm{C}\right), \\
\text { vida hızı }(150-200 \mathrm{dev} / \mathrm{dk}), \\
\text { posa oranı }(\% 2-10 \mathrm{k.b} .) \\
\text { Görünüm, tat, tekstürel } \\
\text { özellikler }\end{array}$ & $\begin{array}{l}\text { CCRD deneme tasarımı } \\
155-160^{\circ} \mathrm{C} \text { kalıp sicaklığı, } \\
\% 4.47-6.57 \text { oranında posa ve } 150- \\
187 \mathrm{dev} / \mathrm{dk} \text { vida hızı }\end{array}$ & $\begin{array}{l}\text { Altan vd., } \\
2008\end{array}$ \\
\hline $\begin{array}{l}\text { Ekstrüde keten } \\
\text { tohumu }\end{array}$ & $\begin{array}{l}\text { Vida hızı }(70-270 \mathrm{dev} / \mathrm{dk}), \\
\text { nem içeriği }(\% 4-28), \text { sicaklık } \\
\left(84-180^{\circ} \mathrm{C}\right), \text { besleme oranı } \\
(25.4-113.4 \mathrm{~kg} / \mathrm{s}) \\
\text { Urünün protein } \\
\text { sindirilebilirliği }\end{array}$ & $\begin{array}{l}\text { CCRD deneme tasarımı } \\
120 \mathrm{dev} / \mathrm{dk} \text { vida hızı, } \\
\% 10 \text { nem içeriği, } 120^{\circ} \mathrm{C} \text { kalıp } \\
\text { sıcaklığ } 1 \text { ve } 91.4 \mathrm{~kg} / \mathrm{s} \text { besleme hız1 }\end{array}$ & $\begin{array}{l}\text { Wang vd., } \\
2008\end{array}$ \\
\hline $\begin{array}{l}\text { Dar1-bakla } \\
\text { ekstrüdatlar1 }\end{array}$ & $\begin{array}{l}\text { Vida hızı, nem içeriği, kalıp } \\
\text { sıcaklığı, karışımdaki baklagil } \\
\text { oranı } \\
\text { Gevreklik, su absorplama } \\
\text { indeksi, yanal genleşme ve } \\
\text { yoğunluk }\end{array}$ & $\begin{array}{l}\text { CCRD deneme tasarımı } \\
\% 23.2 \text { sslak bazda nem içeriği, } \\
\% 19.9 \text { baklagil oranı, } 121.1^{\circ} \mathrm{C} \text { kalıp } \\
\text { sıcaklığ1 ve } 123 \mathrm{dev} / \mathrm{dk} \text { vida hızı }\end{array}$ & $\begin{array}{l}\text { Chakraborty } \\
\text { vd., } 2011\end{array}$ \\
\hline $\begin{array}{l}\text { Bezelye nişastası } \\
\text { eriştesi }\end{array}$ & $\begin{array}{l}\text { Nem içeriği }(\% 30-40) \text {, } \\
\text { sıcaklık }\left(85-100^{\circ} \mathrm{C}\right) \text { ve vida } \\
\text { hızı }(100-200 \mathrm{dev} / \mathrm{dk}) \\
L, a, b \text { değeri, genleşme } \\
\text { oranı, nişasta jelatinizasyonu, } \\
\text { yüzey yapışkanlı̆g }\end{array}$ & $\begin{array}{l}\text { CCRD deneme tasarımı } \\
\% 35 \text { besleme nem içeriği, } 95^{\circ} \mathrm{C} \text { kalıp } \\
\text { sicaklı̆̆ı, } \\
150 \mathrm{dev} / \mathrm{dk} \text { vida hızı }\end{array}$ & $\begin{array}{l}\text { Wang vd., } \\
2012\end{array}$ \\
\hline $\begin{array}{l}\text { Buğday-maş } \\
\text { fasulyesi-yer fistı̆̆1 } \\
\text { ekstrüde ürünleri }\end{array}$ & $\begin{array}{l}\text { Besleme nem içeriği (\%12.6- } \\
\text { 19.4), kalıp sıcaklı̆̆ı (116- } \\
\left.184^{\circ} \mathrm{C}\right) \text { ve vida hızı (349-601 } \\
\text { dev/dk) } \\
\text { Mekanik enerji, genleşme } \\
\text { oranı, yoğunluk, su } \\
\text { absorplama indeksi ve suda } \\
\text { çözünebilirlik indeksi }\end{array}$ & $\begin{array}{l}\text { CCRD deneme tasarım1 } \\
\text { \%14.8 nem içeriği, } \\
521 \mathrm{dev} / \mathrm{dk} \text { vida hızı, } \\
140^{\circ} \mathrm{C} \text { kalıp sıcaklı̆̆1 }\end{array}$ & $\begin{array}{l}\text { Pathania vd., } \\
2013\end{array}$ \\
\hline Çin pirinç şarabı & $\begin{array}{l}\text { Nem içeriği }(\% 33-43), \text { kalıp } \\
\text { sicaklığ }\left(95-105^{\circ} \mathrm{C}\right) \text {, amilaz } \\
\text { konsantrasyonu }(\% 0-1.8) \\
\text { Çin pirinç şarabında } \\
\text { maksimum etanol verimi }\end{array}$ & $\begin{array}{l}\text { CCRD deneme tasarımı } \\
100.14^{\circ} \mathrm{C} \text { kalıp sıcaklı̆̆ı, } \\
\% 43 \text { nem içeriği, } \\
\% 1.45 \text { amilaz konsantrasyonu }\end{array}$ & Li vd., 2014 \\
\hline $\begin{array}{l}\text { Buğday kepeği } \\
\text { ekstrüde ürünü }\end{array}$ & $\begin{array}{l}\text { Kalıp sıcaklı̆̆ } \\
\left(165,175,185^{\circ} \mathrm{C}\right), \\
\text { nem içeriği }(20,25,30 \mathrm{~g} / 100 \mathrm{~g} \\
\text { k.b.), } \\
\text { vida hızı }(180,190,200 \\
\text { dev/dk) } \\
\text { SDF (çözünebilir diyet lifi) } \\
\text { fraksiyonu }\end{array}$ & $\begin{array}{l}\text { Box-Behnken deneme tasarımı } \\
185^{\circ} \mathrm{C} \text { kalıp sıcaklı̆g } 1 \\
24 \mathrm{~g} / 100 \mathrm{~g} \text { besleme nemi, } \\
192 \mathrm{dev} / \mathrm{dk} \text { vida hız1 }\end{array}$ & $\begin{array}{l}\text { Long vd., } \\
2014\end{array}$ \\
\hline
\end{tabular}




\begin{tabular}{|c|c|c|c|}
\hline $\begin{array}{l}\text { Pirinç, manyok } \\
\text { (ekvatoral } \\
\text { ortamlarda yetişen } \\
\text { patates tipi yumru } \\
\text { bitki türü) ve } \\
\text { yerfistığ1 } \\
\text { unlarından } \\
\text { ekstrüde ürün }\end{array}$ & $\begin{array}{l}\text { Besleme nem içeriği, vida hızı } \\
\text { ve kalıp sıcaklı̆̆1 } \\
\text { Yanal genleşme ve raf ömrü }\end{array}$ & $\begin{array}{l}\text { CCRD deneme tasarımı } \\
20 \mathrm{~g} / 100 \mathrm{~g} \text { nem içeriği, } 97^{\circ} \mathrm{C} \text { sıcaklık } \\
\text { ve } 12 \mathrm{dev} / \mathrm{dk} \text { vida hızı }\end{array}$ & $\begin{array}{l}\text { Awolu vd., } \\
2015\end{array}$ \\
\hline $\begin{array}{l}\text { Keten tohumu } \\
\text { atıştırmalıkları }\end{array}$ & $\begin{array}{l}\text { Ekstrüzyon sıcaklığı (100- } \\
\left.160^{\circ} \mathrm{C}\right), \\
\text { vida hızı (60-180 dev/dk), } \\
\text { besleme hızı (\%18.35-54.95 } \\
\mathrm{kg} / \mathrm{s}), \\
\text { nem içeriği (\%14-30 w/w) } \\
\text { invitro protein } \\
\text { sindirilebilirliği, genleşme } \\
\text { indeksi, yığın yoğunluğu ve } \\
\text { tekstürel özellikleri }\end{array}$ & $\begin{array}{l}\text { Genel dört faktörlü karesel tasarım } \\
\text { \%20 keten tohumu içeriği } \\
\% 17.37-22.43 \text { nem içeriği } \\
134.3-156.1^{\circ} \mathrm{C} \text { sicaklık } \\
114-165.7 \mathrm{dev} / \mathrm{dk} \text { vida hızı } \\
34.38-45.95 \mathrm{~kg} / \mathrm{s} \text { besleme hızı }\end{array}$ & $\begin{array}{l}\text { Min vd., } \\
2015\end{array}$ \\
\hline $\begin{array}{l}\text { Fasulye ile } \\
\text { zenginleştirilmiş } \\
\text { atıştırmalıklar }\end{array}$ & $\begin{array}{l}\text { Fasulye unu içeriği } \\
(\% 0-16-30-40), \text { kalıp sıcaklığı } \\
\left(120-170{ }^{\circ} \mathrm{C}\right) \text {, vida hızı }(50- \\
240 \mathrm{dev} / \mathrm{dk}) \\
\text { Genişleme oranı, sertlik, } \\
\text { antioksidan aktivitesi, toplam } \\
\text { fenolik madde içeriği, } \\
\text { melanoidin içeriği }\end{array}$ & 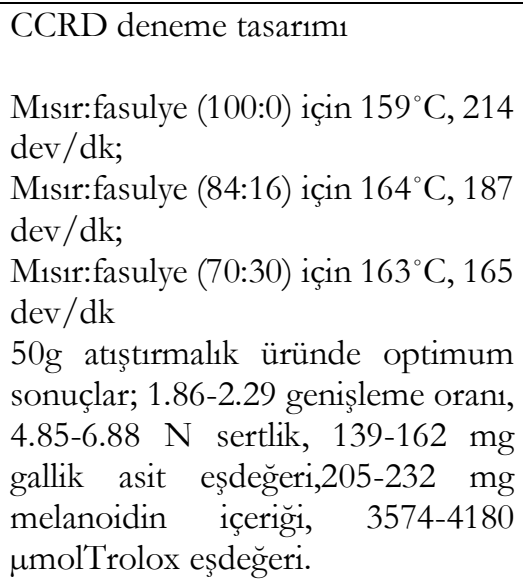 & $\begin{array}{l}\text { Felix- } \\
\text { Medina vd., } \\
2020\end{array}$ \\
\hline
\end{tabular}

Tüketime Hazır ve Atıştırmalık Gıda Ürünlerinde Yapılan Çalışmalar

Tüketiciler tarafindan gündelik yaşamın koşuşturmasında hızlı tüketilebilen ürünler çok tercih edilmekte olup ekstrüzyon pişirme bu konuda önemli bir teknoloji olarak endüstride yerini almıştur.

Shaviklo vd. (2015) yaptıklanı çalışmada, ekstrüde edilmiş mısır ve karidesli atıştırmalık ürününün üretiminde optimum koşulları incelemişlerdir. Bağımsız değişkenler olarak mısır ezmesi, karides tozu ve şeker; yanıt olarak ise duyusal kaliteyi etkileyen koku, lezzet, doku seçilmiştir. Ürünlerin formülasyonunu optimize etmek için üç bileşenli bir D-optimal Karışım tasarımı uygulanmış ve 13 deney oluşturulmuştur. Yüzey kontur grafiklerinde üç faktörün de yanıtları önemli derecede etkilediği görülmüştür. Sonuç olarak 96 $\mathrm{g} / 100 \mathrm{~g}$ misir ezmesi, $3 \mathrm{~g} / 100 \mathrm{~g}$ karides tozu ve 1 $\mathrm{g} / 100 \mathrm{~g}$ şeker içeren karışımın optimum koşullar olduğu ve yanıt değerlerinin ise 6.405 koku, 8.417 lezzet, 8.640 doku olarak tespit edildiği belirtilmiştir.

Alam vd. (2016) tarafindan yapılan çalışmada düşük maliyetli ve besleyici ekstrüde aperatif ürün üretmek için pirinç, yağsız soya fasulyesi unu, havuç posası tozu ve karnabahar tozları içeren karışım hazırlanmıştır. 17 deneysel çalışma sağlayan Box-Behnken yanıt yüzey tasarımı uygulanmıştur. Elde edilen veriler ikinci dereceden 
polinomiyal denkleme uyacak şekilde analiz edilmiştir. Varyans analizi sonucunda kalıp sıcaklığının yanıt üzerindeki en etkili parametre olduğu görülmüsstür. Yanıt yüzey grafiklerinde gözlemlenen sonuçlara göre $\% 76$ oranında kabul edilebilir ekstrüde ürün eldesi için optimum koşulların $164^{\circ} \mathrm{C}$ kalıp sıcaklı̆̆ $1,313 \mathrm{dev} / \mathrm{dk}$ vida hızı ve 85: 7.5: 3.35: 3.25 oranlarında pirinç: yağsız soya unu: havuç püresi unu: karnabahar tozu olduğu bildirilmiştir. Bu şekilde yapılan üretim sonucunda ürünlerin besleyiciliği artmış ve üründe $10.25 \mathrm{~g} / 100 \mathrm{~g}$ protein, $0.84 \mathrm{~g} / 100 \mathrm{~g}$ lif tespit edilmiştir.

Gbenyi vd. (2016) belli oranlarda hazırlanan sorgum ve börülce un karışımlarını tek vidalı ekstrüder kullanarak \%20, \%22.5, \%25 nem değerlerinde ve $120,140, \quad 160^{\circ} \mathrm{C}$ kalıp sıcaklıklarında işleme tabi tutmuşlar ve faktörlerin ekstrüde sorgum-börülce atı̧tırmalık ürünleri üzerindeki etkilerini incelemişlerdir. Ürünlerin viskozite, su absorpsiyon indeksi, suda çözünebilirliği, yanal genişleme ve yığın yoğunluğu değerlerini modellemek için CCRD tasarımı kullanılmışır. Besleme kompozisyonunun sonuç üzerindeki en etkili faktör olduğu bulunmuştur. Yapilan çalışmada, her bir yanıt için değişkenlerin optimum sonuçları ayr1 ayr1 verilmiş olup; besleme kompozisyonu \%11-20.4 arasinda, besleme nemi \% 21.5-25 arasında, ekstrüzyon sicaklığ1 $120-150 \quad{ }^{\circ} \mathrm{C}$ aralığında bulunmuştur. Optimizasyon grafikleri optimum sonuçların $5.8 \mathrm{~g} \mathrm{H}_{2} \mathrm{O} / \mathrm{g}$ ürün su absorpsiyon indeksi, \%14 suda çözünebilirlik indeksi, 3.6 yanal genişleme, $0.24 \mathrm{~g} / \mathrm{cm}^{3}$ yığın yoğunluğu, $10 \mathrm{Ns} / \mathrm{m}^{2}$ viskosize olduğunu göstermiştir.

Bir başka çalışmada yulaf, bezelye, çemen tohumu unundan oluşan sağlıklı ekstrüde atıştırmalık ürünleri üretilmek istenmiştir. Wanive Kumar (2016), bu çalışmada besleme nemi, kalıp sıcaklığ ve vida hızının ekstrüde ürünün yanal genişleme, yığın yoğunluğu, su absorplama indeksi, suda çözünürlüğü ve sertliğine olan etkisi araşturllmıştır. Nem içeriği, sıcaklık ve vida hızı olarak seçilen bağımsız değişkenler için CCRD tasarımı seçilmiştir ve 20 deneme oluşturulmuştur. Üç faktörlü tasarım için ikinci dereceden polinomiyal modeli uygulanmıştır. Yüksek kaliteye sahip ürünün; \%12 nem, $110{ }^{\circ} \mathrm{C}$ ekstrüzyon sıcaklığ1 ve $200 \mathrm{dev} / \mathrm{dk}$ vida hızı değerlerinde üretildiği tespit edilmiş olup, yapilan optimizasyon sonucunda yanıt değerleri; \%112.7 yanal genişleme, $3.9 \mathrm{~g} / \mathrm{g}$ kuru bazda su absorplama kapasitesi, $15.89 \mathrm{~g} / \mathrm{g}$ su absorplama indeksi, $0.22 \mathrm{~g} / \mathrm{cm}^{3}$ yığın yoğunluğu ve sertlik $10.15 \mathrm{~N}$ olarak bulunmuştur.

Xu vd. (2016), 1sıya dayanıklı $\alpha$-amilaz ve ekstrüde edilmiş pirinç unu ile yaptkkları çalışmada enzim konsantrasyonu, kalıp sicaklığı, nem içeriği ve vida hızı olarak belirlenen bağımsız değişkenlerin; üretilen ürünlerin sıcaklığ1, hamur basinc1 ve mekanik enerji gibi proses parametreleri ile jelatinizasyon derecesi, toplam fenolik içeriğinin tutulma oranı değerleri üzerindeki etkisini yanıt yüzey metodu aracillğı ile incelemişlerdir. Bağımsız değişkenler için CCRD tasarımı kullanılmış olup yüzey kontur grafikleri oluşturulmuştur. Çok faktörlü optimizasyona göre; istenilen özelliklere sahip olan ürün özellikleri $10 \mathrm{~kJ} / \mathrm{kg}$ mekanik enerji, \%100 jelatinizasyon derecesi ve $\% 85$ oraninda toplam fenolik maddenin korunmasi olup optimum koşullar; \%1.37 enzim konsantrasyonu, $93.01^{\circ} \mathrm{C}$ kalıp sicaklı̆̆1, \%44.30 nem içeriği ve 171.66 $\mathrm{dev} / \mathrm{dk}$ vida hızı olarak bulunmuştur.

Jozinovic vd. (2017)'nin yaptıkları çalışmanın amaçlarn; süperkritik $\mathrm{CO}_{2}$ ekstraksiyonu tekniği ile tamamen yağsız kenevir keki üretebilmek, ekstrüzyon karışımına yağsız kenevir keki ilavesi ve proses parametrelerinin atısturmalık ürünler üzerindeki etkisini incelemek ve yanıt-yüzey metodu kullanarak ekstrüzyon koşullarında istatistiksel optimizasyonu sağlamaktır. BoxBehnken tasarımı, değişkenleri optimize etmek ve sonuçta üründe en yüksek genişleme oranı (2.77), düşük sertlik (24.95 N), yüksek kirılganlık (10.19 $\mathrm{mm})$ ve çok düşük derecede renk değişimine (14.27) ulaşmak için kullanılmıştır. Mısır irmiğine eklenen yağssz kenevir keki, ekstrüzyon öncesi besleme nem içeriği ve ekstrüzyon sıcaklığı olarak belirtilen her bir faktör için üçer farklı seviye kullanılmıştır. Optimizasyon sonucunda elde edilen veriler; $\% 5$ kenevir keki, $\% 15$ nem içeriği, $150^{\circ} \mathrm{C}$ ekstrüzyon sıcaklığ1 olarak tespit edilmiştir. 
Lohani ve Muthukumarappan (2017) yaptıklar1 çalışmada, sıcak ekstrüzyonla elde edilen ürünlerdeki besinsel ve biyoaktif bileşenlerin kaybını önlemek amacı ile misır unu, sorgum unu ve elma püresi karışımına ekstrüzyon esnasında $\mathrm{CO}_{2}$ püskürtmesi uygulamışlardır. Box-Behnken tasarımı ile 29 deney oluşturulmuştur. Optimum koşullar \%30 elma posası, $25 \mathrm{~g} / 100 \mathrm{~g}$ nem içeriği, $97^{\circ} \mathrm{C}$ ekstrüder sicaklığ1, $100 \mathrm{dev} / \mathrm{dk}$ vida hiz1 olarak belirlenmiştir. Kontrol ekstrüdatları ile karşılaştırıldığında, $\mathrm{CO}_{2}$ ile ekstrüde edilmiş ürünlerin, sistemin soğutma etkisinden ötürü toplam fenolik madde içeriği ( $\% 12$ daha fazla) ve aktioksidan aktivitesi ( $\% 7$ daha fazla) açısından son üründe daha iyi korunduğu görülmüştür.

Topuz vd. (2017) yaptkkları çalışmada yanıt yüzey metodunu kullanarak karides-mısır atıstırmalık ürünü üretmek istemişlerdir. Yanıt-yüzey metodu kullanılarak ekstrüzyon sıcaklığ1 $\left(110-150^{\circ} \mathrm{C}\right)$, vida hız1 (200-500 dev/dk) ve besleme nem değerleri $(17-23 \mathrm{~g} / 100 \mathrm{~g})$ olarak seçilen bağımsız değişkenlere 3'er seviyede Box-Behnken tasarımı uygulanmış ve atıştırmalık ürünlerin fizikokimyasal ve duyusal özellikleri üzerindeki etkileri incelenmiştir. Ekstrüzyon sıcaklığının ürünlerin sertlik, omega-3 yağ asidi ve duyusal özellikleri üzerindeki en etkili faktör olduğu bulunmuştur. $127.2^{\circ} \mathrm{C}$ sıcaklık, $393.4 \mathrm{dev} / \mathrm{dk}$ vida hız1 ve $21.6 \mathrm{~g} / 100 \mathrm{~g}$ nem içeriğinin genel anlamda en kabul edilen ürün için optimum koşullar olduğu bulunmuştur.

Mısır nişastasından çabuk sebze çorbası üretmede ekstrüzyon teknolojisinin kullanım olanağ1 hakkında çalışma yürüten Gandhi vd. (2018), yanıt yüzey metodu-CCRD tasarımı ile 5 seviyede 20 deney gerçekleştirmişlerdir. Besleme nem içeriği, kalıp sıcaklığı ve vida hızının kalite açısından yanitları incelenmiş olup matematiksel modellerin deneysel verilere uyması için regresyon analizi yapılmıştır. Tüm bağımsız değişkenlerin ekstrüde ürün üzerinde önemli bir etkiye neden olduğu görülmüştür. Optimum sonuçlar \%16.13-18 besleme nem içeriği, 400-429 dev/dk vida hızı ve $125-137^{\circ} \mathrm{C}$ kalıp sicaklığ1 olarak; her bir yanitın minimum ve maksimum değer aralığ1; 66.05$111.51 \mathrm{~g} / \mathrm{cm}^{3}$ yığın yoğunluğu, 3.02-4.39 genişleme oranı, \%2.39-3.79 g/g su absorplama indeksi, \%47.12-58.59 suda çözünebilirlik indeksi, $\%$ 59.99-71.17 jelatinizasyon derecesi ve 17.8020.96 nişasta sindirilebilirliği olarak bulunmuştur.

Nakhon vd. (2018) tarafından yapılan çalışmada optimizasyon, yanıt yüzey yöntemi ile gerçekleştirilmiş olup, çimlenmiş kahverengi pirinç ve balkabağı unu ile sağlıklı atıştırmalık üretimi amaçlanmıştır. Çalışmada üç farklı balkabağı unu oranı $(\% 10,20,30)$ ve üç besleme nem içeriği $(\% 13,16,19)$ bağımsız değişkenler olarak seçilmiş ve bu değişkenlerin etkisini incelemek için tamamen rastgele bir tasarımda $3 * 3$ faktöriyel deney tasarımı uygulanmıştır. Sistemde yanıt olarak toplam fenol miktarı ile görünüm ve sertlik gibi duyusal özellikler seçilmiştir. Bağımlı ve bağımsız değişkenler arasındaki ilişki için ikinci dereceden polinomiyalmodel kullanılmıştır. 350 $\mathrm{dev} / \mathrm{dk}$ vida hızı ve $140^{\circ} \mathrm{C}$ ekstrüzyonsıcaklığ1 koşullarında; \%10-13 balkabağ1 unu, \%13-14 besleme nem içeriği optimum koşullar olarak bulunmuştur.

Sukumar ve Athmaselvi (2019) temeli darı olan atıştırmalık ürünü muz tozu ile zenginleştirmişler ve pirinç unu, misır unu ve peynir ile kombine edilerek ekstrüde etmişlerdir. Kalıp sıcaklığ1 (118$\left.122^{\circ} \mathrm{C}\right)$, vida hizı (345-355 dev/dk) ve muz tozu konsantrasyonunun (1-4 g) ekstrüde ürünün fiziksel ve fonksiyonel özellikleri üzerindeki etkileri, yanit-yüzey metodu ve CCRD kullanılarak 3 faktör için 3'er derecede incelenmiştir. Her bir yanıt için regresyon analizi ikinci dereceden polinom modeli kullanılarak yapılmıştır. Bağımsız değişkenlerin yanıtlar üzerinde önemli etkilerinin olduğu tespit edilmiş ve yanıt yüzey grafikleri sonucunda optimum koşulların $119^{\circ} \mathrm{C}$ kalıp s1cakliğ1, $346 \mathrm{dev} / \mathrm{dk}$ vida hizı ve $3.67 \mathrm{~g}$ muz unu konsantrasyonu olduğu bildirilmiştir.

Twum ve Pare (2018) mısır, kahverengi pirinç, tam yağlı soya fasülyesi ve ananas posasının elde edilen ekstrüde ürünlerin fiziksel ve fonksiyonel özelliklerini nasıl etkilediğini incelemek amacıyla optimizasyon çalışması yapmışlardır. Ekstrüder koşulları sabit tutulmuş ve D-Optimal Karışım metodu yardımıyla 20 çalsşma deneyi sağlanarak hamur karısımındaki hammadde oranları optimize edilmiş̧tir. ANOVA ile elde edilen $p$-değerlerine 
bakıldığında soya fasulyesinin fiziksel ve fonksiyonel özellikler üzerinde anlamlı bir etkisinin olmadığ1 tespit edilmiştir. Dolayısıyla, kahverengi pirinç, mısır ve ananas posalarının son ürün üzerinde fiziksel ve fonksiyonel açıdan daha etkili değişkenler olduğu bulunmuştur.

\section{Bebek ve Çocuk Gıdalarında Yapılan Çalışmalar}

Son yıllarda bebek gıdalan hakkında da çalışmalar artmış olup, Ali vd. (2016) ekstrüzyon yöntemi ile yüksek kaliteli ve düşük maliyetli hammaddelerden bebeklerde katı gida başlangıcı için ürün üretmeyi amaçlamışlardır. Çift vidalı ekstrüdere girecek kanısımda maş fasülyesi ve mısır unu (30:70) kullanılmıştır. Nem içeriği, vida hızı ve kalıp sıcaklığı bağımsız değişken olarak seçilmişken, spesifik mekanik enerji, yığın yoğunluğu, su absorpsiyon indeksi, suda çözünebilirlik indeksi ve jelatinizasyon derecesi bağımlı değişken olarak belirlenmiş ve CCRD tasarımında 5'er seviyede çalışılmıstır. 0.065-0.071 $\mathrm{g} / \mathrm{cm}^{3}$ ylğın yoğunluğu, 4.03-4.06 $\mathrm{g} / \mathrm{g}$ su absorplama indeksi, \%29.86-31.67 suda çözünebilirlik indeksi, \%84.82-91.92 jelatinizasyon dereceleri istenen fonksiyonel özellikler olarak belirlenmiştir. Yanıt yüzey metodu ile hedef ürün için elde edilen optimum koşullar; \%14.33 besleme kanışımı nem içeriği, $524 \mathrm{dev} / \mathrm{dk}$ vida hızı, $174^{\circ} \mathrm{C}$ kalıp sıcaklığı olarak tespit edilmiştir.

Atukuri vd. (2018)yüksek protein içeriği ve yüksek protein sindirilebilirliği, düşük yığın yoğunluğu ve düşük viskoziteye sahip bir ürünle ekstrüzyon çalışması yapmak istemişlerdir. $\mathrm{Bu}$ amaçla, duyusal açıdan da kabul edilebilirliği yüksek olan amarantı çalışmalarında kullanmak üzere seçmişler ve bu ürünün tamamlayıcı gıda olarak kullanılabilmesi için optimum ekstrüzyon şartlarını araşturmışlardır. CCRD tasarımı kullanılmıs, veriler ikinci dereceden polinomiyal denkleme işlenmiş ve bağımsız değişkenlerin fonksiyonu yanıt olarak açıklanmıştır. Bağımsız değişkenlerin yanıtlar üzerinde önemli lineer, kuadratik ve interaktif etkilere sahip olduğu ortaya koyulmuştur. Optimizasyon sonucunda; $150^{\circ} \mathrm{C}$ ekstrüder sıcaklığ1, $50 \mathrm{~Hz}$ vida hızı, \%14.41 nem içeriği optimum koşullar olarak bulunmuş ve elde edilen verilerin $\% 71$ oranı ile kabul edilebilirliğe sahip olduğu tespit edilmiştir.

Mangaraj vd. (2018), 9-18 yaş arasındaki çocuklarda hastalık kaynaklı beslenme yetersizliği ile mücadele etmek için zenginleştirilmiş ekstrüde ürün üretmişlerdir. Bu amaçla mısır ve pirinç unu bazlı üründe yağsız soya unu, soya protein izolat1, kahve beyazlatıcısı, mango ve 1spanak ürünleri ile çalışışlardır. Hammaddelerin beslemeye giren karışımdaki oranları ve bu hammaddelerin kendi aralarındaki etkileşimlerinin, atıştırmalık ürünlerin beslenme kriterleri üzerindeki etkilerini değerlendirebilmek için yanıt yüzey metodu kullanılmıştır. Protein ve yağ içeriği en yüksek ürün, 35:35:15:10:5 oranlarındaki mısır: pirinç: yağsız soya unu: kahve beyazlatıcısı: soya protein izolat ile sağlanmıştr. Tat, koku, renk, görünüm ve genel olarak kabul edilebilirlik gibi duyusal özellikler açısından en yüksek değeri,10 üzerinden 7.46 puanı ile mango içeren ürün vermiștir. Duyusal açıdan 0.88 değeri ile kabul edilebilirlik açısından en yüksek sonucu, $\% 10$ yağsız soya unu ve $\% 5$ soya protein izolatı vermiş ve soya bazlı ürünlerin anlamlı sonuç verdiği görülmüştür. Tüm ürünler için değişkenler ve yanıtlar arasında iyi bir uyum olduğu görülmüştür.

\section{Makarna Ürünlerinde Yapılan Çalışmalar}

Wang vd. (2016)' nin yaptıkları çalışmada ekstrüzyon sıcaklığı ve vida hızının, temel bileşeni kahverengi pirinç unu olan glutensiz makarna ürününe etkisini yanıt-yüzey metodu kullanarak bulmayı amaçlamışlardır. Bağımsız değişkenlerin ürünün pişme ve tekstürel kalitesi üzerinde önemli derecede etkili olduğu fakat eğilimlerin farklı olduğu belirlenmiştir. $120^{\circ} \mathrm{C}$ ve $120 \mathrm{dev} / \mathrm{dk}$ vida hızına sahip ekstrüder koşullarında üretilen ürünlerin diğer glutensiz ürünlere kıyasla benzer özelliklere sahip olduğu ve kahverengi pirincin bu sektörde kullanılabileceği görülmüştür. Ayrıca yapılan optimizasyon sonucunda $\% 6.7$ pişme kaybı, 2387.2 g sertlik, -7 g.s yapışkanlık değerleri bulunmuştur.

Sobowale vd. (2018) yaptıkları çalışmada cocoyam (tropik bölgelerde yetişen nişasta içeriği yüksek sebze) eriştelerinin kalite özelliklerinde besleme nem içeriği, vida hızı ve kalıp sıcaklığının etkilerini 
yanit yüzey metodu-CCRD deneme tasarımı ve 20 deney ile açıklamışardır. Sonuçta; kanısım kompozisyonu, termo-fiziksel ve fizikokimyasal özellikler ve eriştelerin renkleri ekstrüzyon parametrelerinden önemli derecede etkilenmiştir. $\% 47.5$ besleme nem içeriği, $700 \mathrm{dev} / \mathrm{dk}$ vida hızı ve $55^{\circ} \mathrm{C}$ kalıp sicaklığ olarak elde edilen optimum koşullarla üretilen eriştelerin, duyusal açıdan da en kabul edilebilir özelliklere sahip ürünler olduğu bulunmuştur.

Spinelli vd. (2019), yaptıkları çalışmada gıda yan ürün/atıkları ile zenginleştirilmiş makarna üretmeyi hedeflemişlerdir. $\mathrm{Bu}$ amaçla misır kepeği, üzüm posası tozu, bira endüstrisinde yan ürün olan tahıl unu olmak üzere 3 farklı yan ürün/atık kullanılmıştrr. Yöntem, toplam kalite indeksinin optimizasyonu olarak açıklanmıştır. Toplam fenolik madde içeriği bakımından \%15 tahıl unu ya da \%15 üzüm posasi; duyusal özellik bakımından $10 \mathrm{~g} / 100 \mathrm{~g}$ tahil unu, $8.5 \mathrm{~g} / 100 \mathrm{~g}$ üzüm posas1 ya da $11 \mathrm{~g} / 100 \mathrm{~g}$ misır kepeği en yüksek sonucu vermiştir. Toplam kalite indeksinin maksimumda olduğu değerler ise yaklaşık \%10 tahıl unu, $\% 9$ üzüm posası tozu ya da $\% 10 \mathrm{misir}$ kepeği olarak bulunmuştur. Sonuçlar, üründe hem duyusal hem de besinsel özellikleri yüksek tutarak zenginleştirilmiş makarna üretilebileceğini göstermiştir.

\section{SONUÇ VE TARTIŞMA}

Gida ekstrüzyon teknolojisi son yllarda atışırmalık gıda ürünleri, tüketime hazır çabuk çorba, erişte ürünleri, bebek ve çocuk gidaları vb. gibi pek çok ürün grubunda tercih edilmektedir. $\mathrm{Bu}$ durumda, hem yaşam koşullarının tüketicileri hızlı ve çabuk gıdalara yönlendirmesi hem de ekstrüzyonun enerji tüketiminin az olmas1, üretimin verimli ve son ürünün ucuz olmas1, yeni teknolojilerden olması, yüksek sıcaklık-kısa süreli işleme yöntemi olması gibi diğer teknolojilere göre olumlu özelliklerinin olması etkilidir. Ekstrüzyon yönteminde ürün özelliklerine etkide bulunan birden çok faktör bulunmaktadır. Dolayısıyla istenilen özelliklere sahip ürünü elde etmek için fazlasiyla deney gerekmektedir. Bu nedenle deney sayısını azaltmaya yardımcı, optimum bağımsız değişken verilerini bulabilen optimizasyon yöntemine başvurulmaktadır. $\mathrm{Bu}$ derlemede ekstrüzyon yöntemi ile üretilmiş ürünlerdeki optimizasyon çalışmaları araşturılmıştır. Yapılan optimizasyon çalışmalannda yanıt yüzey metotları kullanılarak CCRD, Box-Behnken, D-Optimal Karışımı gibi deney tasarımları yapılması, regresyon analizlerinin gerçekleştirilmesi ve ANOVA ile değerlendirme neticesinde hedeflenen ürünlere ulaşmada olumlu sonuçlar elde edildiği görülmüştür.

\section{ÇIKAR ÇATIŞMASI BEYANI}

Yazarlar, başka kişiler ve/veya kurumlar ile çıar çatışması olmadığını beyan eder.

\section{YAZAR KATKILARI}

AMB, derlemenin araştırma, yazma-orijinal taslak, görselleştirme ve incelemesine katkıda bulunmuştur. ŞT, yazma-orijinal taslak ve inceleme-düzenleme aşamalarında danışman olarak katkı sağlamıştır. Yazarlar makalenin son halini okumuş ve onaylamıştır.

\section{KAYNAKLAR}

Ackar, D., Jozinovic, A., Babic, J., Milicevic, B., Balentic, J.P., Subaric, D. (2018). Resolving the problem of poor expansion in corn extrudates enriched with food industry by-products.Innov. Food Sci. Emerg., 47:517-524.

Ajita, T. (2018). Extrusion Cooking Technology: An Advance Skill for Manufacturing of Extrudate Food Products. In: Extrusion of Metals, Polymers and Food Products, Qamar, S. Z. (chief ed.), pp. 197210.http://dx.doi.org/10.5772/intechopen.7349 6.ISBN: 978-953-51-3838-9.

Alam, M.S., Pathania, S., Sharma, A. (2016). Optimization of the extrusion process for development of high fibre soybean-rice ready-toeat snacks using carrot pomace and cauliflower trimmings.Food Sci. Technol., 74:135-144.

Ali, S., Singh, B., Sharma, S. (2016). Response surface analysis and extrusion process optimisation of maize-mungbean-based instant weaning food.Food Sci. Technol., 51: 2301-2312.

Altan, A., McCarthy, K.L., Maskan, M. (2008). Twin-screw extrusion of barley-grape pomace blends:Extrudate characteristics and 
determination of optimum processing conditions.J. Food Eng., 89:24-32.

Atukuri, J., Odong, B.B., Muyonga, J.H. (2018). Multi-response optimization of extrusion conditions of grain amaranth flour by response surface methodology.Food Sci. Nutr., 7:4147-4162, doi:10.1002/fsn3.1284.

Awolu, O.O., Oluwaferanmi, P.M., Fafowora, O.I., Oseyemi, G.F. (2015). Optimization of the extrusion process for the production ready-to-eat snack from rice, cassava and kersting's groundnut composite flours.Food Sci. Technol., 64:18-24.

Aydar, A.Y. (2018). Utilization of Response Surface Methodology in Optimization of Extraction of Plant Materials. http://dx.doi.org/10.5772/intechopen.73690.

Aydar, A.Y. (2019). Statistical Methods in Optimization of Food Materials. European Int J. Sci Technol, 8(3): 33-40. https://orcid.org/0000-00019780-0917

Bastos, G.M., Junior, M.S.S., Caliari, M., Araujo Pereira, A.L., Morais, C.C., Campos, M.R.H. (2016). Physical and sensory quality of gluten-free spaghetti processed from amaranth flour and potato pulp.Food Sci. Technol., 65:128-136.

Cappa, C., Franchi, R., Bogo, V., Lucisano, M. (2017). Cooking behavior of frozen gluten-free potato-based pasta (gnocchi) obtained through turbo cooking technology.Food Sci. Technol., 84:464-470.

Cardenes-Hernandez, A., Beta, T., Loarca-Pina, G., Castano-Tostado, E., Nieto-Barrera, J. O., Mendoza, S. (2016). Improved Functional Properties of Pasta: Enrichment with amaranth seed flour and dried amaranth leaves.J. Cereal Sci., 72: 84-90.

Chakraborty, S.K., Singh, D.S., Kumbhar, B.K., Chakraborty, S. (2011). Millet-legume blended extrudates characteristics and process optimization using RSM.Food Bioprod. Process., 89:492-499. doi:10.1016/j.fbp.2010.10.003.

Danbaba, N., Iro, N., \& Mamudu, H. B. (2016). Application of Response Surface Methodology (RSM) for the production and optimization of extruded instant porridge from broken rice fractions blended with Cowpea. Int. J. Food Sci. Nutr., 5: 105-116.

Felix-Medina, J.V., Montes-Avila, J., ReyesMoreno, C., Perales-Sanchez, J. X. K., GomezFavela, M. A., Aguilar-Palazuelos, E., GutierrezDorado, R. (2020). Second-generation snacks with high nutritional and antioxidant value produced by an optimized extrusion process from corn/common bean flours mixtures. Food Sci. Technol., 124: 1-8. https://doi.org/10.1016/j.lwt.2020.109172.

Gandhi, N., Singh, B., Sharma, S., Kapoor, S. (2018). Extrusion process optimization of corn starch to develop instant vegetable soup mix.Int. J. Curr. Microbiol. Appl. Sci., 7(2):2886-2910.

Gbenyi, D.I., Nkama, I., Badau, M.H. (2016). Physical and Functional Properties of Extruded Sorghum-Cowpea Blends: A Response Surface Analysis.Food Sci. Qual. Manag., Vol50. ISSN 2224-6088 (Paper), ISSN 2225-0557 (Online).

Giuberti, G., Gallo, A., Cerioli, C., Fortunati, P., Masoero, F. (2015). Cooking quality and starch digestibility of gluten free pasta using new bean flour.Food Chem., 175:43-49.

Helkar, P.B., Sahoo, A. (2016). Review: Food industry by-products used as a functional food ingredients.Int. J. Waste Resour., 6(3): 1-6.

Jozinovic, A., Ackar, D., Jokıc, S., Babıc, J., Balentic, J.P., Banozic, M., Subarıc, D. (2017). Optimisation of extrusion variables for the production of corn snack products enriched with defatted hemp cake. Crech J. Food Sci, 35(6):507516. doi:10.17221/83/2017-CJFS.

Koç, B., Kaymak-Ertekin, F. (2010). Yanıt Yüzey Yöntemi ve Gıda İşleme Uygulamaları.GID $A$, 35(1):1-8.

Li, H., Wei, B., Wu, C., Zhang, B., Xu, X., Jin, Z., Tian, Y. (2014). Modelling and optimisation of enzymatic extrusion pretreatment of broken rice for wine manufacture.Food Chem., 150:94-98.

Lohani, U.C., Muthukumarappan, K. (2017). Process optimization for antioxidant enriched sorghum flour and apple pomace based extrudates using liquid $\mathrm{CO}_{2}$ assisted extrusion.Food Sci. Technol., 86:544-554. 
Long, D., Ye, F., Zhao, G. (2014). Optimization and characterization of wheat bran modified by in situ enhanced $\mathrm{CO} 2$ blasting extrusion.Food Sci. Technol., 59:605-611.

Lu, X., Brennan, M.A., Serventi, L., Liu, J., Guan, W., Brennan, C.S. (2018). Addition of mushroom powder to pasta enhances the antioxidant content and modulates the predictive glycaemic response of pasta.Food Chem., 264:199-209, doi: 10.1016/j.foodchem.2018.04.130.

Mangaraj, S., Swain, S., Deshpande, S.S. (2018). Development of Extruded Functional Snack Foods from Plants and Dairy Ingredients Employing Response Surface Methodology.J. Dairy Vet. Sci., ISSN:2573-2196. V:7, Issue4.

Maskan, A. (ed.), Altan, A. (ed.). (2012). Advances In Food Extrusion Technology.CRC Press,412 p. ISBN:13:978-1-4398-1521-2 (e-Book Pdf), Version date: 20110829.

Min, W., Yi, L., Lijun, W., Dong, L., Zhihuai, M. (2015). Effects of extrusion parameters on physicochemical properties of flaxseed snack and process optimization.Int. J. Agric. and Biol. Eng., 8(5):121-131.

Nakhon, P.P.S., Jangchud, K., Jangchud, A., Charunuch, C.(2018). Optimization of pumpkin and feed moisture content to produce healthy pumpkin-germinated brown rice extruded snacks. Agric. Nat. Resour., 52:550-556.

Navale, S.A., Swami, S.B., Thakor, N.J. (2015). Extrusion Cooking Technology for Foods: A Review.J. Ready Eat Food, 2(3): 66-80.

Ovando-Martinez, M., Sayago-Ayerdi, S., AgamaAcedevo, E., Goni, L., Bello-Perez, L.A. (2009). Unripe banana flour as an ingredient to increase the undigestible carbohydrates of pasta.Food Chem., 113: 121-126.

Pathania, S., Sing, B., Sharma, S., Sharma, V., Singla, S. (2013). Optimization of extrusion processing conditions for preparation of an instant grain base for use in weaning foods. Int. J. Eng. Res. Appl., 3(3):1040-1049.

Patino-Rodriguez, O., Bello-Perez, L.A., FloresSilva, P.C., Sanchez-Rivera, M.M., RomeroBastida, C.A. (2018). Physicochemical properties and metobolomic profile of gluten-free spaghetti prepared with unripe plantain flours.Food Sci. Technol., 90:297-302.

Rajesvari, G., Susanna, S., Prabhasankar, P., Venkateswara-Rao, G. (2013). Influence of onion powder and its hydrocolloid blends on pasta dough, pasting, microstructure, cooking and sensory characteristics.Food Biosci., 4:13-20, doi: 10.1016/j.fbio.2013.07.004.

Rizvi, S.H., Paraman, I. (2015). Extrusion of Agro-food industry byproducts and protein concentrates into value-added foods. United States Patent Application Publication, Pub.No.: US 2015/0282507 A1., Pub. Date: Oct 8, 2015.

Sawant, S.S., Thakor, N.J., Swami, S.B. (2015). Application of Extrusion Cooking Technology In Food Industry. Int. J. Process. Postharvest Technol., 6(2):177-183, doi: 10.15740/HAS/IJPPHT/6.2/177-183.

Sharma, R., Srivastava, T., Saxena, D. C. (2016). Development of nutritious snack from rice industry waste using twin screw extrusion. MATEC Web of Conferences 57,04006.

Shaviklo, A.R., Azaribeh, M., Moradi, Y., Zangeneh, P. (2015). Formula optimization and storage stability of extruded puffed corn-shrimp snacks.Food Sci. Technol., 63:307-314. http://dx.doi.org/10.1016/j.lwt.2015.03.093

Silva, E., Sagis, L.M.C., Van der Linden, E., Scholten, E. (2013). Effect of matrix and particle type on rheological, textural and structural properties of broccoli pasta and noodles.J. Food Eng.,119: 94-103.

Sobowale, S.S., Animashaun, O.H., MulabaBafubiandi, A.F., Abidoye, T.S., Kewuyemi, Y.O., Adebo, O.Y. (2018). Process optimization of extusion variables and its effect on properties of extruded cocoyam (Xanthosoma sagittifolium) noodles.Food Sci. Nutr., 1-17.

Surasani, V.K.R. (2016). Application of food extrusion process to develop fish meat-based extruded products.Food Eng. Rev., 8:448-456. doi:10.1007/s12393-016-9148-0.

Spinelli, S., Padalino, L., Costa, C., Nobile, M.A.D., Conte, A. (2019). Food by-products to 
fortified pasta:A new approach for optimization.J. Cleaner Pro., 215:985-991.

Sukumar, A., Athmaselvi, K.A. (2019). Optimization of process parameters for the development of finger millet based multigrain extruded snack food fortified with banana powder using RSM.J. Food Sci. Technol., 56(2):705712.

Tiğa, B. H. (2018). Düşük Yağ İçerikli Tüketime Hazır Erişte Üretimi ve Teknolojik Özelliklerinin İncelenmesi. Ege Üniversitesi Fen Bilimleri Enstitüsü Gıda Mühendisliği Anabilim Dalı Yüksek Lisans Tezi, İzmir, Türkiye, $100 \mathrm{~s}$.

Topuz, O.K., Gokoğlu, N., Jouppila, K., Kirjoranta, S.(2017). Development of Extruded Shrimp-Corn Using Response Surface Methodology.Turk J. Fish. Aquat. Sci., 17:333-343.

Torres-Leon, C., Ramires-Guzman, N., Londono-Hernandez, L., Martinez-Medina, G.A., Diaz-Herrera, R., Navarro-Macias, V., AlvarezPerez, O.B., Picazo, B., Villarreal-Vazquez, M., Ascacio-Valdez, J., Aguilar, C.N. (2018). Food waste and by-products: an opportunity to minimize malnutrition an hunger in developing countries.Front. Sustain. Food Syst., 2(52): 1-17, doi: 10.3389/fsufs.2018.00052.

Twum, L.A., Pare, A. (2018). Development and Optimization of the Physical and Functional Properties of Extruded Products.Curr. J. Appl. Sci. Technol., 29(2): 1-11. ISSN: 2457-1024.

Waldron, K. (2007). Handbook of Waste Management and Co-product in Food Processing. 305-377, eBook
ISBN: $\quad 9781845692520, \quad$ Published Date:31.03.2007.

Wang, Y., Li, D., Wang, L.J., Chiu, Y.L., Chen, X.D., Mao, Z.H., Song, C.F. (2008). Optimization of extrusion of flaxseeds for in vitro protein digestibility analysis using response surface methodology.J. Food Eng., 85: 59-64.

Wang, N., Maximiuk, L., Toews, R. (2012). Pea starch noodles: Effect of processing variables on characteristics and optimisation of twin-screw extrusion process.Food Chem., 133:742-753.

Wang, L., Duan, W., Zhou, S., Qian, H., Zhang, H., Qi, X. (2016). Effects of extrusion conditions on the extrusion responses and the quality of brown rice pasta.Food Chem., 204: 320-325.

Wani, S.A., Kumar, P. (2016). Development and parameter optimization of health promosing extrudate based on fenugreek oat and pea.Food Biosci., 14:34-40. http://dx.doi.org/10.1016/j.fbio.2016.02.002.

Xu, E., Pan, X., Wu, Z., Long, J., Li, J., Xu, X., Jin, Z., Jiao, A. (2016). Response surface methodology for evaluation and optimization of process parameter and antioxidant capacity of rice flour modified by enzymatic extrusion.Food Chem., 212:146-154.

Yolmeh, M., Jafari, S.M. (2017). Applications of Response Surface Methodology in the Food Industry Processes.Food Bioprocess Tech., 10: 413433, doi: 10.1007/s11947-016-1855-2. 